Article

\title{
The Effect of Parties on Voters' Satisfaction with Democracy
}

\author{
Miroslav Nemčok \\ University of Helsinki, 00170 Helsinki, Finland; E-Mail: miroslav.nemcok@helsinki.fi
}

Submitted: 15 February 2020 | Accepted: 26 May 2020 | Published: 17 July 2020

\begin{abstract}
Electoral 'winners' (i.e., voters casting a ballot for a party included in the post-electoral government) are acknowledged to be more satisfied with democracy than supporters of opposition parties. However, little is known about the influence of parties and their specifics on the boost in satisfaction with democracy experienced by their voters. To address this question, the research utilizes 17 surveys from 12 countries included in the European Social Survey rounds 1-8, for which a government replacement took place during the survey period. This allows this research to employ discontinuity design and examine the effect of two attributes related to parties-differences in party vote shares, and voters' feeling of closeness to a party. The findings suggest that these factors have a negligible influence on voters' satisfaction with democracy and only scant evidence is found that closeness to a party tends to increase their satisfaction. When voters' attitudes from before and after a government replacement are compared, changes in government do not seem to strike voters as a surprise and thus they do not cause any sudden and lasting changes in the general attitudes of electorates. Nevertheless, this indicates a novel contribution to the literature: the effect of losing needs some time to fully develop until it results in a decrease in satisfaction level. Based on these findings, the research concludes that when it comes to parties' characteristics, it is primarily the government/opposition status which determines voters' degree of satisfaction with democracy.
\end{abstract}

\section{Keywords}

democracy; democratic quality; electoral behaviour; European Social Survey; government; political parties

\section{Issue}

This article is part of the issue "Populism and Polarization: A Dual Threat to Europe's Liberal Democracies?" edited by Jonas Linde (University of Bergen, Norway), Marlene Mauk (GESIS - Leibniz Institute for the Social Sciences, Germany) and Heidi Schulze (GESIS-Leibniz Institute for the Social Sciences, Germany).

(C) 2020 by the author; licensee Cogitatio (Lisbon, Portugal). This article is licensed under a Creative Commons Attribution 4.0 International License (CC BY).

\section{Introduction}

Voters' political support for democratic systems and satisfaction with their performance constitute an essential element for the sustainability of democratic regimes (Claassen, 2019). Therefore, it can hardly be surprising that this topic has been extensively addressed in political science research. The results convincingly show that electoral winners-i.e., voters casting a ballot for a party included in the post-electoral government-tend to be more satisfied with democracy compared to the supporters of opposition parties (Anderson, Blais, Bowler, Donovan, \& Listhaug, 2005; Blais \& Gélineau, 2007; Singh, 2014). The strong empirical evidence supporting winners' satisfaction is explained by their anticipation that the winning parties will deliver in line with their election pledges (Singh, Karakoç, \& Blais, 2012; Thomson et al., 2017).

Even though political parties are facilitating the link between citizens and democratic institutions, we know surprisingly little about their moderating effect on the boost in satisfaction with democracy experienced by their voters. This gap in the literature stems from the unavailability of suitable data. Cross-sectional surveys conducted after elections enable researchers to study satisfaction among voters of specific parties (e.g., Anderson et al., 2005; Bernauer \& Vatter, 2012; Dassonneville \& McAllister, 2020). However, such surveys cannot study the size of the boost voters experienced due to the absence of pre-electoral attitudes which are essential to measure the changes over time. On the other hand, panel surveys conducted before and after elections can 
capture the boost (e.g., Blais \& Gélineau, 2007; Blais, Morin-Chassé, \& Singh, 2017; Singh, 2014). However, they are expensive and only allow researchers to examine a single election or a few elections and subsequent government replacements. This does not offer enough variance in the characteristics of parties to generalize their impact on the size of the satisfaction boost among voters.

This research overcomes these methodological shortcomings thanks to an innovative approach to the European Social Survey (ESS). The study utilizes the fact that due to its extensive questionnaire, ESS data collection in participating countries takes several months. Moreover, ESS is a cross-sectional survey hence data are gathered simultaneously without any significant attention paid to the national political processes and context. Thanks to that, government replacements (following a national election) reshuffled the winner/loser status among voters during several data collection periods. This allows the research to split these samples and apply discontinuity research design to analyse the differences in people's satisfaction before and after government replacements. A sufficiently large number of responses before and after a government replacement was collected in 17 surveys conducted in 12 countries (i.e., Austria, Belgium, Cyprus, Estonia, Iceland, Ireland, Italy, Lithuania, The Netherlands, Portugal, Sweden, and Slovenia) which constitutes a sample large enough to examine the moderating effect of parties and party-related characteristics on the changes in voters' satisfaction with democracy.

The research examines two party-related factors which are expected to influence voters' satisfaction with democracy: differences in party election vote shares and voters' feeling of closeness to a party. Available empirical evidence suggests that a tighter bond between the voters and a party increases the voters' satisfaction among winners as well as among losers. However, when voters' satisfaction with democracy is compared before and after government replacements, neither a sudden boost nor a decay can be detected. On the one hand, this suggests that the replacement of parties in the government does not strike voters as a surprise and their attitudes change in a continuous nature. However, on the other hand, a steady level of satisfaction among voters who have become electoral losers (i.e., when one's party loses its position in the government) indicates that the effect of losing needs some time to fully develop until it results in a decrease in satisfaction levels among voters.

\section{Satisfaction with Democracy: Review of Relevant Findings}

Every democratic system thrives on popular support and withers in its absence (Claassen, 2019), and consequently people's attitudes towards democracy have gathered increasing attention among scholars. The rich body of research has examined the abundant amount of empirical evidence and has repeatedly arrived at two major factors which now stand at the centre of almost all attempts to explain voters' satisfaction with democracy. The first factor deals with electoral choice and stipulates that electoral winners-i.e., those who voted for a party which formed the post-electoral government-tend to express a higher level of satisfaction with the performance of democracy in their country when compared to voters of the opposition parties (e.g., Anderson et al., 2005; Bernauer \& Vatter, 2012; Singh, 2014). This gap between winners and losers has been reported by the vast majority of studies.

Going one step further, the findings from panel studies comparing individuals' pre- and post-election attitudes suggest that this boost is driven by the expectation that the incoming government will implement policies that match the voters' interests (Singh, 2014; Singh et al., 2012; Thomson et al., 2017). At the same time, losers' disappointment stems from the realization that the country will be run by a government which overlaps with their preferences to a very limited extent or not at all (Singh et al., 2012).

Despite this being the predominant definition of winning in political science (especially in research conducted in Anglo-Saxon world), it is also acknowledged that voters for parties that were not elected into government may still feel like winners in some respects. Such a situation may appear, e.g., if voters, regardless of their vote choice, are still ideologically close to the newly composed post-electoral government (Curini, Jou, \& Memoli, 2012). Considering the size of representation, Blais et al. (2017, p. 85) "affirm that voting for parties that win more votes, more legislative seats, and more cabinet seats boosts satisfaction with democracy." This suggests that acquiring legislative seats may already cause a satisfaction boost among voters (Singh et al., 2012), especially if they support a new party without any prior incumbency experience. Even though these alternative measures of winning matter, Stiers, Daoust, and Blais (2018) convincingly demonstrate that in the voters' perception a comparatively much stronger indication of winning is voting for the party which becomes the largest party in the election and leads the government formation process. Given this direct evidence, the research follows the conventional definition of winning based on a party's inclusion in the government. Nevertheless, this research also tackles the influence of party vote (and seat) shares on winners' and losers' satisfaction with democracy. If different vote/seat shares are found to influence winners' or losers' satisfaction levels, it is a sign that alternative definitions of winning deserve closer attention among scholars.

The second factor builds on the assumption that winning and losing mean different things in majoritarian and consensual systems. This direction of research has been triggered by Anderson and Guillory (1997), who conclude:

Losers in systems that are more consensual display higher levels of satisfaction with the way democracy 
works than do losers in systems with majoritarian characteristics. Conversely, winners tend to be more satisfied with democracy the more a country's political institutions approximate pure majoritarian government. (Anderson \& Guillory, 1997, p. 66)

Majoritarian systems are expected to generate big winners benefitting from the strong position of single party governments which can directly proceed to implement their election pledges (Lijphart, 2012, pp. 9-29). However, this necessarily means that only negligible attention is paid to losers' preferences. Consequently, the gap in satisfaction between winners and losers tends to get larger. Consensual systems, on the other hand, are expected to be governed by coalition formations that result from government negotiations; thus, electoral winners anticipate that part of their preferences will not be implemented (Lijphart, 2012, pp. 30-45). This limits the size of satisfaction boost they experience. At the same time, consensual systems offer more opportunities to influence the political decision-making process for the losing minorities, hence their satisfaction is not as low as the losers' satisfaction in majoritarian systems (Anderson \& Guillory, 1997; Bernauer \& Vatter, 2012). In general, due to distinctive incentives which influence the form of governance in these systems, it is expected that the winner-loser gap will be larger in systems with majoritarian electoral rules compared to systems with proportional mechanisms (Gallagher \& Mitchell, 2008).

This modifying effect of the electoral system on the satisfaction gap presented by Anderson and Guillory (1997) has found supportive (e.g., Farrell \& McAllister, 2006; Klingemann, 1999), albeit mixed evidence (e.g., Aarts \& Thomassen, 2008; Berggren, Fugate, Preuhs, \& Still, 2004; McAllister, 2005). The latter studies pointed towards other factors possibly influencing the winnerloser gap, such as economic inequality (Han \& Chang, 2016), voters' degree of control over the resulting political representation (Bosch \& Orriols, 2014; Pellegata \& Memoli, 2018), ideological proximity (Curini et al., 2012; Ezrow \& Xezonakis, 2011), the intertemporal dimension of winning (Chang, Chu, \& Wu, 2014), strategic voting (Singh, 2014), the availability of direct political participation for losers (Bernauer \& Vatter, 2012), and electoral margins (Howell \& Justwan, 2013).

Considering the size of this literature and how consistently it attaches voters' satisfaction to the position of political parties within the governing structures, it is surprising how little attention has been paid to the characteristics of political parties. Moreover, political parties are perceived as a link between citizens and democratic systems, therefore, the contemporary decline of parties should raise concerns about citizens' support for democracy and the subsequent sustainability of democratic regimes (see Mair, 2013). Even though satisfaction with democracy fluctuates over time, the trends do not seem to correlate with any measures that aim to capture the so-called 'legitimacy crises' in Western Europe (van Ham, Thomassen, Aarts, \& Andeweg, 2017).

As a response to this discrepancy, Andeweg and Farrell (2017) argue that political parties still contribute their support for the democratic systems. However, it does not happen via membership and "individually engaging citizens in party activities, but by collectively offering citizens a meaningful choice" (Andeweg \& Farrell, 2017 , p. 93), which could be seen in voters' continuously persisting (and sometimes even increased) feeling of closeness to one or several political parties. Hooghe and Kern (2015) have analysed political trust and arrived at essentially the same conclusion: Citizens who feel closeness to a political party are more likely to reveal higher levels of political trust.

The strong link between parties and citizens' political support led Dassonneville and McAllister (2020) to study people's satisfaction with democracy across different party systems. They examined the three main characteristics of party systems - the number of parties, the degree of polarization, and representativeness-however, weak evidence compelled them to conclude that the main effects of these indicators were not found to be associated with higher levels of satisfaction with democracy. However, when it comes to democratic stability, the institutionalization of political parties and the institutionalization of party systems can represent two distinctive processes (Casal Bértoa, 2017), and a comprehensive study of political parties on satisfaction with democracy has been missing. This article aims to fill this gap by presenting an analysis of how party election vote shares, and voters' feeling of closeness to a party influence satisfaction with democracy among voters.

\subsection{Size of the Win: Party Vote Shares}

Just as winning can mean different things in different systems, so winners embedded in the same institutional environment can have different experiences of winning. The reason is that despite the constant institutional setup, a party's electoral result determines its strength to implement policy priorities and it is the expectation that voters' priorities will be implemented that increases winners' satisfaction with democracy (Singh, 2014; Singh et al., 2012; Thomson et al., 2017).

If big winners in majoritarian systems enjoy an additional degree of satisfaction thanks to the stronger position of their party in the post-electoral government (Anderson \& Guillory, 1997; Bernauer \& Vatter, 2012), then the same should apply to those voters who experience a big win in other systems too. Consequently, voters for parties occupying a stronger representative position in a system also demonstrate higher levels of satisfaction with democracy (Blais et al., 2017; Singh et al., 2012).

This line of thinking is also supported by Stiers et al. (2018), who designed a survey to explore what makes people believe that their party won the election. Paying close attention to the individual level, their main dis- 
covery is that "supporters of the largest party-the party with most votes and seats in both Parliament and government-almost unanimously believe that their party won the election" (Stiers et al., 2018, p. 21). This study supplies evidence suggesting that voters' perception of winning is influenced by the vote shares received by parties in elections.

Therefore, voters' satisfaction with democracy should grow together with the party vote share as a direct indicator of the party's strength in a system.

\subsection{Closeness to a Party}

The success of a party supported by an individual constitutes a strong predictor for their satisfaction with democracy (Anderson et al., 2005; Blais et al., 2017). In addition, being close to a party also has major importance for an individual's satisfaction with democracy (Andeweg \& Farrell, 2017; Hooghe \& Kern, 2015). Since both these tendencies deal with the influence of parties on individuals' satisfaction with democracy, it is reasonable to expect that these two factors operate together and influence each other.

This expectation finds support from political psychology, which confirmed "the role of enduring partisan commitments in shaping attitudes toward political object" (Campbell, Converse, Miller, \& Stokes, 1960, p. 135). People's viewpoints regarding party achievements have been found to be distorted by a 'perceptual screen' which tends to bias perception of political facts depending on the strength of the attachment between a voter and a party (Brader \& Tucker, 2012). This tendency has been demonstrated by Stiers and Dassonneville (2018) using exit polls from Belgium to conclude that voters with a strong party identification are more optimistic in evaluating their party's electoral performance. Singh (2014) also demonstrates that the effect of winning is especially pronounced for those voters who disclosed stronger psychological bonds to the parties they voted for. As their subjective perception might be biased upwards, they are likely to be especially delighted by a party's success, but also less affected by its defeat.

Therefore, considering the partisan bias, if voters feel close to a party who are election winners, they should reveal higher satisfaction with democracy compared to voters without partisan attachments. In the case of a party losing, positive partisan bias should contribute to a steady level of satisfaction among voters who identify with a party, whereas satisfaction among voters without partisan attachments should decrease.

\section{Data and Methods}

This research applies an innovative methodological approach to the survey analysis. It utilizes the fact that due to its extensive questionnaire, the data collection for ESS takes several months. Thanks to the cross-sectional nature of the ESS, which does not pay attention to the political development in participating countries, government replacements sometimes take place during the survey data collection period and reshuffle the status of winners and losers among voters. This offers an opportunity to use the date of an interview to position respondents in a specific point in time and compare the differences in people's satisfaction with democracy before and after a government replacement (Muñoz, Falcó-Gimeno, \& Hernández, 2020; see Figure 1).

\subsection{Data}

The study utilizes the ESS cumulative data rounds 1 to 8 (2002-2016), which is a cleaned and harmonized compilation of the ESS rounds. For rounds 1 and 2, ESS indicates the exact date when an interview was conducted. For rounds 3 to 8 , ESS includes the starting and ending date of the interview. Individuals were positioned on a timeline according to the starting date of their interviews, and those observations for which the difference between the starting and ending date was up to 10 days were included (to ensure that the final dataset includes reliably marked dates).

Analysis focuses on voters' attitudes revealed during the period of 30 days before and 30 days after elections or government replacement. This is an arbitrary cut-off point that is set with respect to the data specifics. In the shortest instances, interviews are available for the period preceding or following a government replacement (see Figure A1 in the Supplementary File). Hence, setting the cut-off point to thirty days allows one to compare similar pre- and post-government replacement periods across

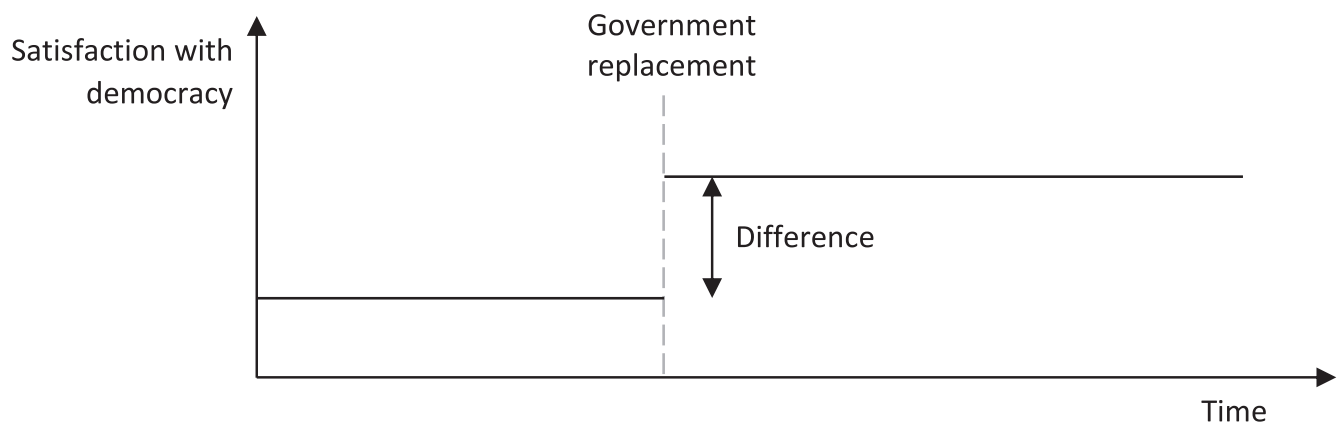

Figure 1. Methodological approach: Discontinuity during survey data collection. 
all cases. A data summary with respect to interview timing is presented in Table A1 in the Supplementary File. For timing of the ESS data collection periods with respect to government replacement and preceding election dates, see Figure 2.

\subsection{Variables}

The main dependent variable is the satisfaction with democracy measured by the question: "And on the whole, how satisfied are you with the way democracy works in [country]?" Respondents were offered an 11-point scale with two anchors ( $0=$ extremely dissatisfied; $10=$ extremely satisfied). As has been demonstrated by Linde and Ekman (2003), this question taps voters' satisfaction with the performance of democratic institutions rather than support for the general principles of democracy. Some authors have demonstrated that this question conceptually overlaps with other indicators, such as party preference or executive approval (e.g., Canache, Mondak, \& Seligson, 2001). However, as Anderson points out, "in the absence of a better item...the satisfaction with democracy measure is a reasonable (albeit imperfect) indicator that we can use to test our theories" (Anderson, 2002, p. 10).

An electoral winner has been consistently defined by the literature as casting a ballot for a party that is included in the government (Anderson et al., 2005; Blais et al., 2017; Singh, 2014; Singh et al., 2012). Since this research design uses the date of a government replacement as a cut-off point, the coding of winners and losers is straightforward-those who voted for a party included in the government during their interview were coded as winners. Opposition party voters were coded as losers. Abstainers were excluded from the sample. However, the primary focus of this analysis is towards the status change and its association with the change in the degree to which voters are satisfied with democracy. Therefore, the samples were split into four categories-became winner, became loser, stayed winner, and stayed loser-which are included in the regression models as dummies.

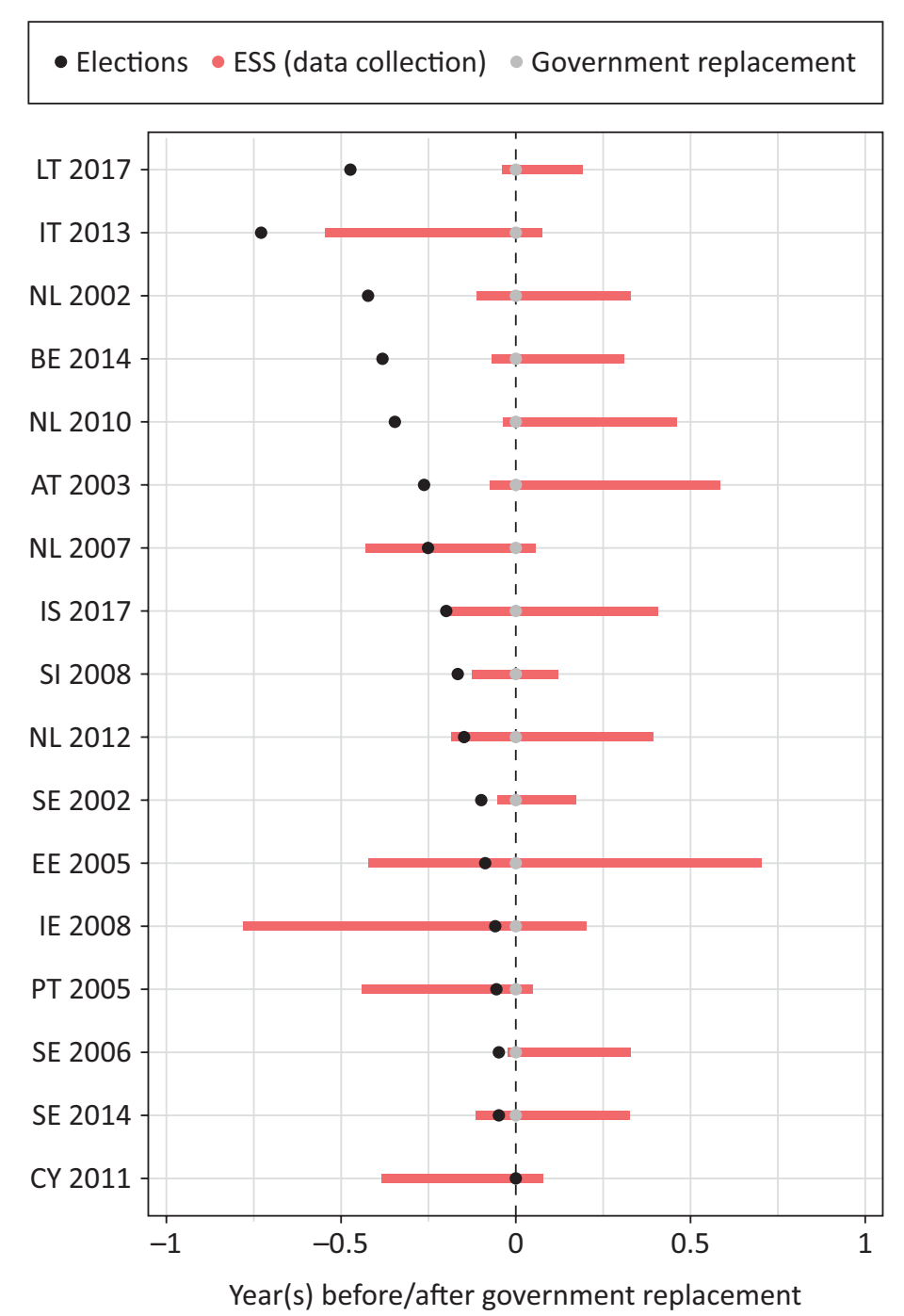

Figure 2. Overview of survey data collection periods, and dates of government replacements and preceding elections. 
Closeness to a party was measured by a question included in the ESS: "Is there a particular political party you feel closer to than all the other parties?" (1 = yes; $0=$ no).

Party election votes shares were taken from the ParlGov database (Döring \& Manow, 2019). However, in order to take into account the previous position of the party, the analysis uses the party vote share differences between the two preceding elections.

Regarding individual-level controls, the ESS database permits controlling for age (in years), gender ( $1=$ female; $0=$ male), education (completed 1 = less than lower secondary education; 2 = lower secondary education; 3 = upper secondary education; $4=$ post-secondary nontertiary education; $5=$ tertiary education), and satisfaction with the state of the economy $(0=$ extremely dissatisfied; 10 = extremely satisfied). In addition to these personal background characteristics, the analysis controls for the time gap (measured in days) between the individual interview and the government replacement date.

\subsection{Method and Visualization Strategy}

With respect to the method, the presented findings are the results of the OLS regression analysis. Due to data specifics, some models include survey fixed effects (executed as survey dummies) to control for the effect of inter-country variations. Due to the interactive nature of the research design and proposed hypotheses, some regression models implement three- or four-way interactions. Following the suggestions by Brambor, Clark, and Golder (2006), interpretation of interaction terms always relies on the visualization of respective models, which are included in the Supplementary File. This seeks to increase the readability of this article.

To make visualizations easier to examine, they are always split into two parts. The first part compares satisfaction levels among those who became winners with those who remained losers. The logic is to use the steady degree of satisfaction with democracy among those whose status did not change (i.e., stayed electoral losers) as a baseline in order to expose the changes in the satisfaction among those who experience change in their status (i.e., became electoral winners). Both these groups consist of losers during the period preceding a government replacement and therefore should reveal comparable levels of satisfaction with democracy. However, their status starts to differ from the day of a government replacement, which is expected to introduce a satisfaction boost among the new electoral winners. This difference, if there is any, represents the effect of winning we aim to tackle.

The second part applies a similar logic. Steady satisfaction levels among those who remained electoral winners are used as a baseline in order to reveal changes in the satisfaction levels among those who became electoral losers. Both these groups consist of winners during the period preceding a government replacement and therefore the expected decrease in the satisfaction levels revealed by electoral losers represent the estimated effect of losing, if there is any effect, on one's satisfaction with democracy.

\section{Results}

The empirical analysis begins with a basic comparison of changes in satisfaction with democracy associated with winner/loser status change. Overall, the trends seem to follow the findings presented in the literature (e.g. Anderson et al., 2005; Singh, 2014; Singh et al., 2012)winners tend to be more satisfied with the way democracy works in their country. Satisfaction with democracy among those who became winners, stayed winners, or became losers is higher compared to the voters whose parties were included in the opposition during the whole time (see Table A2 in the Supplementary File, and Figure 3 in this article). This suggests two things: First, the satisfaction of those who are about to become winners already increases during the period before a new government is officially appointed to office (see left panel in Figure 3). This is because the new government formation is often increasingly apparent as time goes by after elections (Loveless, 2020; van der Meer \& Steenvoorden, 2018). Second, those who became losers do not reveal an immediate and rapid drop in their satisfaction with democracy (see right panel in Figure 3). Hence, it seems to take some time until the effect of losing representation in the government fully develops and results in a drop in satisfaction among supporters of these parties.

However, the degree of satisfaction with democracy across all four groups tends to be stable through the whole period under investigation (see Figure 3). When satisfaction levels are compared before and after a government replacement, the differences are not significant and therefore this democratic event does not seem to introduce rapid and sudden discontinuities into voters' attitudes.

\subsection{Party Vote Shares}

When it comes to the party vote shares, tested expectation is built on the proposition that big winners should demonstrate a higher degree of satisfaction with democracy. Before interpreting the findings, it is important to note that some specific situations-such as becoming a winner when one's party loses $10 \%$ votes or becoming a loser when one's party gains more than $10 \%$ of votes compared to the previous elections are rare. This is the reason why confidence intervals in the upper left and lower right panels in Figure 4 expand so much compared to other parts of the figure. This creates some concerns about the reliability of the trends. Unfortunately, the data used for this research cannot be expanded at the present time, hence it remains a task for future research to validate these findings. 


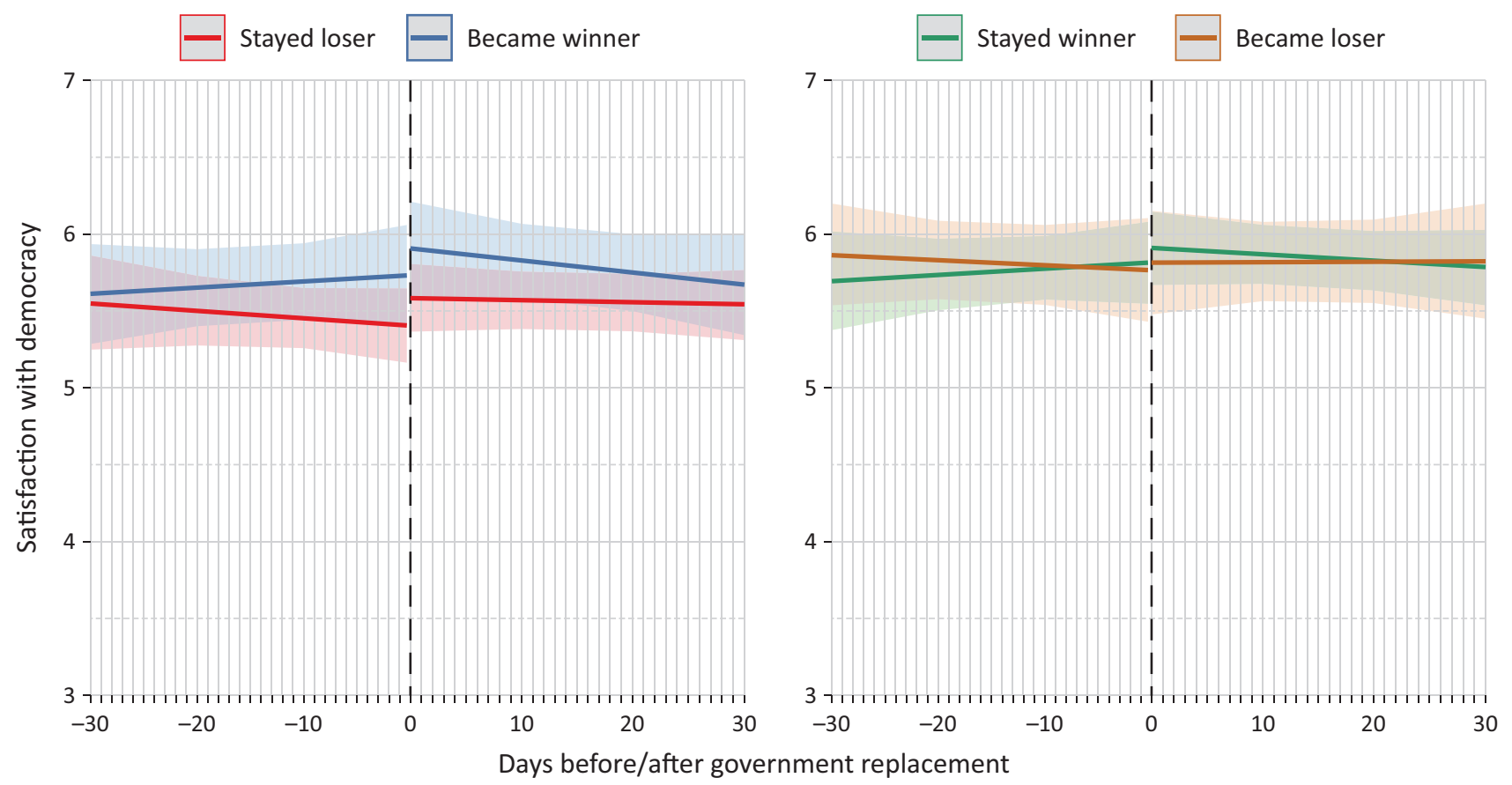

Figure 3. Comparison of pre- and post-government replacement satisfaction among four categories of winner/loser status change. Note: The marginal effects of the interaction terms from Model 4 in Table A2 of the Supplementary File are visualized.

The findings based on the full Model 4 (in Table A3 in the Supplementary File) controlling for all confounders including the survey fixed effects do not indicate that the differences in party vote share are associated with neither a higher nor a lower degree of satisfaction with democracy among voters. The upper half of Figure 4 suggests that the trends are contrary to initial expectations. The gap between those who became winners and stayed losers gets narrower as the party vote share difference increases. Nevertheless, the lower part of Figure 4 indicates that the difference in vote shares received by a party does matter among those who remained winners. Despite the lack of any discontinuity observable around the government replacement date, the satisfaction among continuous winners increases from roughly 5.5 points (on a $0-10$ scale) to roughly 6 points. This indicates that the effect of party strength within a system may be more nuanced and applies only to those voters whose parties gain executive power to implement their election pledges. Among losers, it does not seem to have a systematic influence on their satisfaction levels.

The effect of government change does not introduce a sharp change to people's satisfaction with democracy and from this perspective it also seems to be negligible in this case. When satisfaction levels from before and after a government replacement are compared, the difference is not statistically significant and therefore a government's replacement does not seem to introduce major discontinuities into voters' attitudes.

One may argue, however, that the differences in vote shares do not have to be an accurate measure of winning.
Due to various aspects of electoral systems, changes in vote shares do not have to reflect changes in the party seat shares, which better reflect the actual strength of the party in a political system. If voters' satisfaction with democracy increases with the power held by chosen parties (Blais et al., 2017; Singh, 2014; Singh et al., 2012; Thomson et al., 2017), then it should rather be associated with the seat shares occupied by political parties. To mitigate this concern, a robustness check included in the Supplementary File replicates this part of the analysis with differences in seat shares rather than vote shares. The results are almost identical (see Table A4 and Figure A2 in the Supplementary File). Therefore, whether one examines differences in vote shares or differences in seat shares has no impact on the results presented in this section.

\subsection{Closeness to a Party}

When party identification is examined, the findings suggest that the satisfaction with democracy among those feeling close to a party tends to be higher (see Table A5 in the Supplementary File). The estimated marginal effects displayed in Figure 5 indicate that satisfaction with democracy tends to be higher (by a quarter to a half of a point on an 11-point scale) among those who stayed winners or became winners, especially if we focus on the period following a government replacement. Therefore, interaction between party closeness and winner status may be a relevant factor that contributes to the expansion of the winner-loser gap in democratic systems. However, the confidence intervals often overlap, hence 

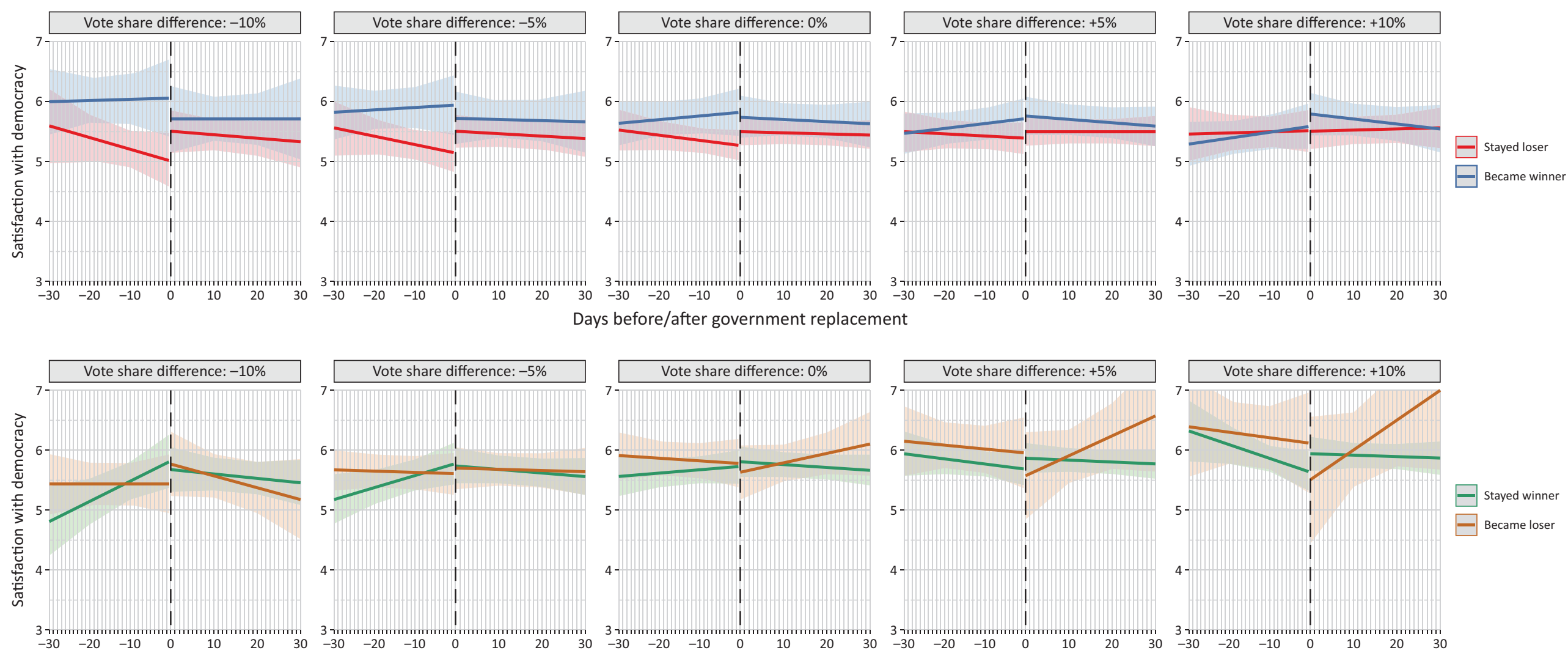

Days before/after government replacement
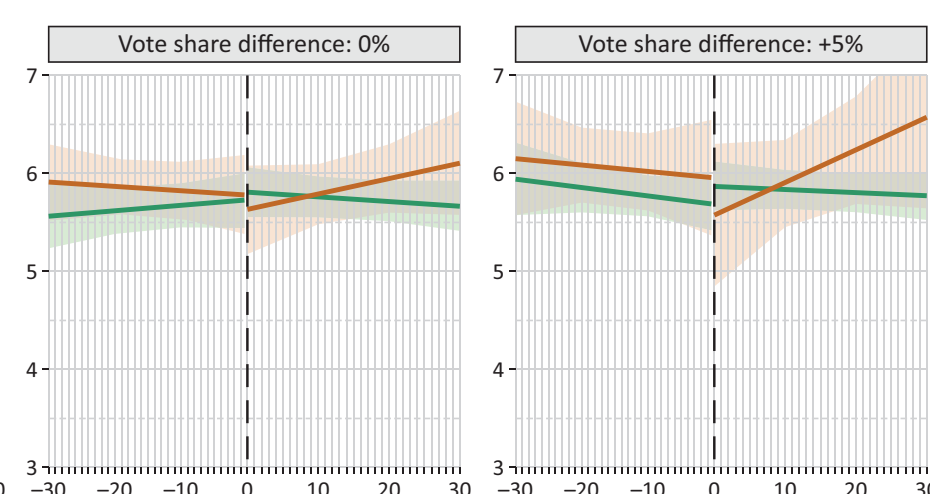

Days before/after government replacement

Figure 4. Comparison of estimated pre- and post-government replacement satisfaction among winners and losers depending on party vote shares. Note: The marginal effects of the interaction terms from Model 4 in Table A3 of the Supplementary File are visualized. 

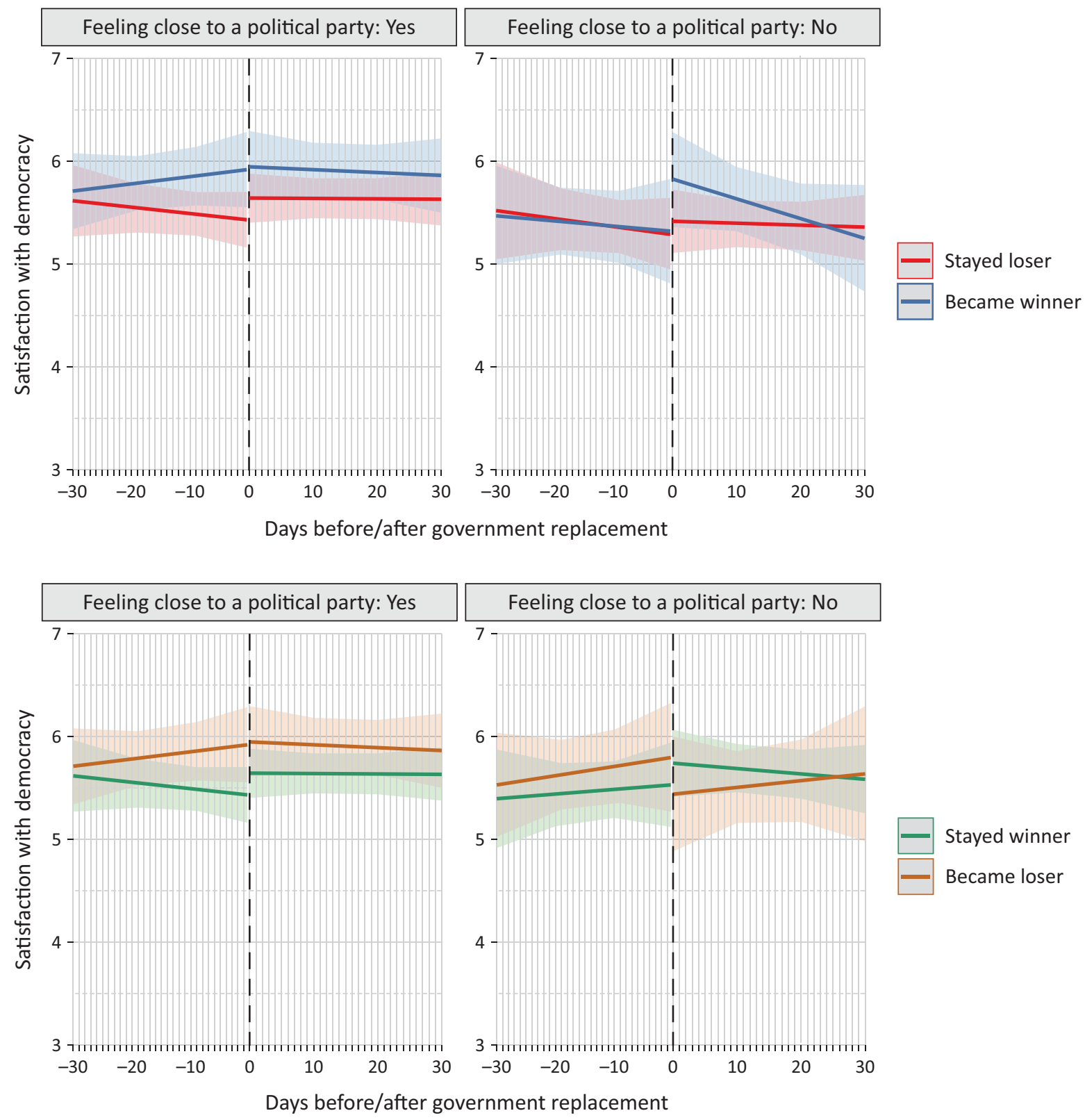

Figure 5. Comparison of estimated pre- and post-government replacement satisfaction among winners and losers between voters who do or do not feel close to a party. Note: The marginal effects of the interaction terms from Model 4 in Table A5 of the Supplementary File are visualized.

this finding has to be taken as indicative, rather than conclusive, for the future direction of research.

This part of the analysis also suggests that those whose party is excluded from government (i.e., those who became losers) do not reveal a sudden change in their satisfaction levels. Thus, it seems that the effect of becoming a loser requires some time until it develops and results in a decrease in satisfaction with democracy.

When pre- and post-government replacement satisfaction levels are compared, the only noteworthy discontinuity is a sudden boost in satisfaction among those who became winners and do not feel close to a party (see upper right panel in Figure 5). However, satisfaction among members of this group returns close to the levels among those who stayed losers during the 30 days following a government replacement. Therefore, the installation of a new government does not seem to interact with voters' partisan identification in a systematic pattern that would significantly alter the boost or decay in satisfaction levels of any of the groups.

\section{Discussion and Conclusions}

The research applied an innovative methodological approach to the ESS data. Based on the interview date, individuals were positioned in a specific point in time before and after a government replacement in order to examine the effect of party-related attributes on the degree of sat- 
isfaction with democracy among their supporters. The research examined two party-related factors-differences in election vote shares, and voters' feeling of closeness to a party-which were theorized to have an influence on voters' levels of satisfaction with democracy.

The presented evidence provides two additional contributions to this body of knowledge. First, when voters' self-declared closeness to a party is examined, the findings indicate that the satisfaction with democracy among those feeling close to a party tends to be higher. This applies to electoral winners as well as losers. Therefore, the party closeness status may constitute a relevant factor providing part of the explanation for the varying levels of satisfaction with democracy observed across contemporary democratic systems. However, given the low statistical power of these results, it has to be taken only as an indicative finding for future research to confirm or deny.

Second, the introduced methodological approach allowed a comparison of the levels of satisfaction among voters on an aggregated level before and after a government replacement. No major discontinuities were identified-i.e., neither a sudden boost nor a sharp drop is detectable in the voters' aggregated attitudes emerging shortly after a government change. The lack of any major discontinuity persists after inclusion of any partyrelated factors. Therefore, government changes do not seem to strike voters as a surprise (a condition especially emphasized by Muñoz et al., 2020), and they do not cause sudden overall changes in aggregated levels of satisfaction with democracy in electorates. This finding nevertheless provides a novel contribution. Steady levels of satisfaction with democracy among individuals who become electoral losers (i.e., their party lost its position in the government) indicates that the effect of losing needs some time to fully develop until it results in a decrease of voters' satisfaction levels.

The lack of discontinuities contrasts with the panel surveys analysing the micro-level changes by, e.g., Blais and Gélineau (2007), Blais et al. (2017), and Singh et al. (2012), which all identified relevant individual-level processes in the development of pre- and post-election attitudes. Hence, this study suggests that these micro-level effects only translate into the macro-level functioning of systems to a limited degree.

\section{Acknowledgments}

This research has greatly benefitted from the feedback received at the EUROLAB Authors' Conference 'Populism and polarization: A dual threat to Europe's liberal democracies?' (21-22 November 2019 at GESIS in Cologne, Germany) and the 'Linking Survey and Context Data to Analyze Elite and Mass Interactions' workshop (26-27 September 2019 at University of Vienna, Austria). The author would like to acknowledge the financial support provided by the Finnish Cultural Foundation (Suomen Kulttuurirahasto).

\section{Conflict of Interests}

The author declares no conflict of interest.

\section{Supplementary Material}

Supplementary material for this article is available online in the format provided by the author (unedited).

\section{References}

Aarts, K., \& Thomassen, J. (2008). Satisfaction with democracy: Do institutions matter? Electoral Studies, 27(1), 5-18. https://doi.org/10.1016/j.electstud. 2007.11.005

Anderson, C. J. (2002). Good questions, dubious inferences, and bad solutions: Some further thoughts on satisfaction with democracy. Unpublished manuscript.

Anderson, C. J., Blais, A., Bowler, S., Donovan, T., \& Listhaug, O. (2005). Losers' consent: Elections and democratic legitimacy. Oxford: Oxford University Press. https://doi.org/10.1093/0199276382.001. 0001

Anderson, C. J., \& Guillory, C. A. (1997). Political institutions and satisfaction with democracy: A crossnational analysis of consensus and majoritarian systems. American Political Science Review, 91(1), 66-81. https://doi.org/10.2307/2952259

Andeweg, R. B., \& Farrell, D. M. (2017). Legitimacy decline and party decline. In R. A. C. van Ham, J. Thomassen, \& K. Aarts (Eds.), Myth and reality of the legitimacy crisis: Explaining trends and crossnational differences in established democracies (pp. 76-94). Oxford: Oxford University Press.

Berggren, H. M., Fugate, G. a., Preuhs, R. R., \& Still, D. R. (2004). Satisfied? Institutional determinants of citizen evaluations of democracy. Politics \& Policy, 32(1), 72-96. https://doi.org/10.1111/j.1747-1346. 2004.tb00176.x

Bernauer, J., \& Vatter, A. (2012). Can't get no satisfaction with the Westminster model? Winners, losers and the effects of consensual and direct democratic institutions on satisfaction with democracy. European Journal of Political Research, 51(4), 435-468. https:// doi.org/10.1111/j.1475-6765.2011.02007.x

Blais, A., \& Gélineau, F. (2007). Winning, losing and satisfaction with democracy. Political Studies, 55(2), 425-441. https://doi.org/10.1111/j.14679248.2007.00659.x

Blais, A., Morin-Chassé, A., \& Singh, S. P. (2017). Election outcomes, legislative representation, and satisfaction with democracy. Party Politics, 23(2), 85-95. https://doi.org/10.1177/1354068815583200

Bosch, A., \& Orriols, L. (2014). Ballot structure and satisfaction with democracy. Journal of Elections, Public Opinion and Parties, 24(4), 493-511. https://doi.org/ $10.1080 / 17457289.2014 .888434$ 
Brader, T., \& Tucker, J. A. (2012). Following the party's lead: Party cues, policy opinion, and the power of partisanship in three multiparty systems. Comparative Politics, 44(4), 403-420.

Brambor, T., Clark, W. R., \& Golder, M. (2006). Understanding Interaction models: Improving empirical analyses. Political Analysis, 14(1), 63-82.

Campbell, A., Converse, P. E., Miller, W. E., \& Stokes, D. E. (1960). The American voter. Ann Harbor, MI: University of Michigan Press.

Canache, D., Mondak, J. J., \& Seligson, M. A. (2001). Meaning and measurement in cross-national research on satisfaction with democracy. Public Opinion Quarterly, 65(4), 506-528. https://doi.org/ $10.1086 / 323576$

Casal Bértoa, F. (2017). Political parties or party systems? Assessing the 'myth' of institutionalisation and democracy. West European Politics, 40(2), 402-429. https://doi.org/10.1080/01402382.2016.1216921

Chang, E., Chu, Y., \& Wu, W. (2014). Consenting to lose or expecting to win? Inter-temporal changes in voters' winner-loser status and satisfaction with democracy. In J. Thomassen (Ed.), Elections and democracy: Representation and accountability (pp. 232-254). Oxford: Oxford University Press. https://doi.org/ 10.1093/acprof:oso/9780198716334.003.0012

Claassen, C. (2019). Does public support help democracy survive? American Journal of Political Science. https://doi.org/10.1111/ajps.12452

Curini, L., Jou, W., \& Memoli, V. (2012). Satisfaction with democracy and the winner/loser debate: The role of policy preferences and past experience. British Journal of Political Science, 42(2), 241-261. https://doi. org/10.1017/S0007123411000275

Dassonneville, R., \& McAllister, I. (2020). The party choice set and satisfaction with democracy. West European Politics, 43(1), 49-73. https://doi.org/ 10.1080/01402382.2019.1609286

Döring, H., \& Manow, P. (2019). Parliaments and governments database (ParlGov): Information on parties, elections and cabinets in modern democracies: Development version. ParlGov. Retrieved from http:// www.parlgov.org/data/table/view_election

Ezrow, L., \& Xezonakis, G. (2011). Citizen satisfaction with democracy and parties' policy offerings. Comparative Political Studies, 44(9), 1152-1178. https://doi. org/10.1177/0010414011405461

Farrell, D. M., \& McAllister, I. (2006). Voter satisfaction and electoral systems: Does preferential voting in candidate-centred systems make a difference? European Journal of Political Research, 45(5), 723-749. https://doi.org/10.1111/j.1475-6765.2006.00633.x

Gallagher, M., \& Mitchell, P. (2008). The politics of electoral systems. Oxford: Oxford University Press.

Han, S. M., \& Chang, E. C. C. (2016). Economic inequality, winner-loser gap, and satisfaction with democracy. Electoral Studies, 44, 85-97. https://doi.org/ 10.1016/j.electstud.2016.08.006
Hooghe, M., \& Kern, A. (2015). Party membership and closeness and the development of trust in political institutions: An analysis of the European Social Survey, 2002-2010. Party Politics, 21(6), 944-956. https:// doi.org/10.1177/1354068813509519

Howell, P., \& Justwan, F. (2013). Nail-biters and nocontests: The effect of electoral margins on satisfaction with democracy in winners and losers. Electoral Studies, 32(2), 334-343. https://doi.org/10.1016/ j.electstud.2013.02.004

Klingemann, H.-D. (1999). Mapping political support in the 1990s: A global analysis. In P. Norris (Ed.), Critical citizens: Global support for democratic government (pp. 31-56). Oxford: OxfordUniversity Press. https:// doi.org/10.1093/0198295685.003.0002

Lijphart, A. (2012). Patterns of democracy: Government forms and performance in thirty-six countries (2nd ed.). New Haven, CT: Yale University Press.

Linde, J., \& Ekman, J. (2003). Satisfaction with democracy: A note on a frequently used indicator in comparative politics. European Journal of Political Research, 42(3), 391-408. https://doi.org/10.1111/1475-6765. 00089

Loveless, M. (2020). When you win, nothing hurts: The durability of electoral salience on individuals' satisfaction with democracy. Political Studies. https://doi. org/10.1177/0032321720910356

Mair, P. (2013). Ruling the void: The hollowing of western democracy. London: Verso.

McAllister, I. (2005). Accountability, representation and satisfaction with democracy. International Journal of Public Opinion Research, 17(3), 371-379. https://doi. org/10.1093/ijpor/edh097

Muñoz, J., Falcó-Gimeno, A., \& Hernández, E. (2020). Unexpected event during survey design: Promise and pitfalls for causal inference. Political Analysis, 28(2), 186-206. https://doi.org/10.1017/pan.2019.27

Pellegata, A., \& Memoli, V. (2018). Corruption and satisfaction with democracy: The conditional role of electoral disproportionality and ballot control. European Political Science Review, 10(3), 393-416. https://doi. org/10.1017/S1755773917000200

Singh, S. (2014). Not all election winners are equal: Satisfaction with democracy and the nature of the vote. European Journal of Political Research, 53(2), 308-327. https://doi.org/10.1111/1475-6765. 12028

Singh, S., Karakoç, E., \& Blais, A. (2012). Differentiating winners: How elections affect satisfaction with democracy. Electoral Studies, 31(1), 201-211. https://doi.org/10.1016/j.electstud.2011.11.001

Stiers, D., Daoust, J.-F., \& Blais, A. (2018). What makes people believe that their party won the election? Electoral Studies, 55, 21-29. https://doi.org/ 10.1016/j.electstud.2018.07.002

Stiers, D., \& Dassonneville, R. (2018). Affect versus cognition: Wishful thinking on election day: An analysis using exit poll data from Belgium. International Jour- 
nal of Forecasting, 34(2), 199-215. https://doi.org/ 10.1016/j.ijforecast.2017.12.001

Thomson, R., Royed, T., Naurin, E., Artés, J., Costello, R., Ennser-Jedenastik, L., . . Praprotnik, K. (2017). The fulfillment of parties' election pledges: A comparative study on the impact of power sharing. American Journal of Political Science, 61(3), 527-542. https:// doi.org/10.1111/ajps.12313

van der Meer, T. W. G., \& Steenvoorden, E. H. (2018).
Going back to the well: A panel study into the election boost of political support among electoral winners and losers. Electoral Studies, 55, 40-53. https:// doi.org/10.1016/j.electstud.2018.06.007

van Ham, C., Thomassen, J., Aarts, K., \& Andeweg, R. (2017). Myth and reality of the legitimacy crisis: Explaining trends and cross-national differences in established democracies. Oxford: Oxford University Press.

\section{About the Author}

Miroslav Nemčok is a Finnish Cultural Foundation Postdoctoral Research Fellow at the University of Helsinki and a Research Specialist at the Masaryk University in the Czech Republic. His research focuses on electoral systems, satisfaction with democracy among citizens, and political participation. He has published in Party Politics, European Political Science Review, Journal of Elections, Public Opinion and Parties, among others. 